\section{Maria de Lourdes de Andrade Massara(a) $^{(a)}$ Marcelo Bönecker ${ }^{(b)}$}

(a) Department of Pediatric Dentistry and Orthodontics, School of Dentistry, Federal University of Minas Gerais - UFMG, Belo Horizonte, MG, Brazil.

(b) Department of Pediatric Dentistry, School of Dentistry, University of Sao Paulo - USP, São Paulo, SP, Brazil.

\title{
Modified ART: Why not?
}

W henever an innovative approach is published, it becomes public domain. It prompts queries, reflections, assimilations and new studies. Modifications may ensue as an upshot of having to tailor this approach to the reality in which it will be applied. This is precisely what occurred when the Atraumatic Restorative Treatment (ART) proposal was announced in Brazil, at a conference during the $5^{\text {th }}$ World Congress on Preventive Dentistry, held in the city of São Paulo, in $1995 .{ }^{1}$

The term Modified Atraumatic Restorative Treatment (ARTm) was first made known to the dental community in early $2000^{2-4}$ and gained followers over the years, both in public service and private practice. Nonetheless, errors were made in relation to understanding the terminology and applying the technique. For this reason, it has become meaningful to discuss what led the technique to be partially modified, what its indications are, and why it is important.

In 1995, the ART proposal made its greatest impact in our field on how we deal with dentinal lesions. The conventional treatment (use of anesthesia, rubber dam isolation and complete removal of carious dentin with a rotary instrument) had been the most widely used procedure up until then. The cavity was excavated by manual instrument only in temporary approaches, ultimately followed by reopening of the cavity for a new dentin intervention and completion of the restorative treatment. These approaches were restricted to two situations. The first was in stabilizing the oral environment, when several lesions were sealed temporarily with zinc oxide-eugenol cement, using the stepwise excavation technique (SE). The second was in the case of deep lesions, using indirect pulp capping (IPC) to avoid pulp exposure.

When ART was first made known to the Brazilian dental community, the reliability of the technique was questioned by its professionals. On the other hand, those who were already using less invasive therapies understood ART as a reinterpretation of SE and IPC. They accepted the fact that the complete removal of softened dentinal tissue-irreversibly compromised-using only manual instruments and no anesthesia could be considered a form of definitive cavity preparation, followed by immediate restoration of the cavity in a single session. Not only was the technique innovative, it also had a tremendous impact on Pediatric Dentistry, because its "atraumatic" element would greatly influence the behavioral adaptation of children and adolescents.

When the technique was introduced into clinical practice, it became apparent that the exclusion of a rotary instrument would limit applying this approach to all dentinal lesions, ${ }^{2}$ a prospect later substantiated. The minimum opening required for a dentinal lesion on the occlusal surface using the ART approach is $1.6 \mathrm{~mm}$ in diameter. The reason for this limitation is that the size of the access significantly affects the efficacy of de- 
mineralized tissue removal by manual instruments. ${ }^{5}$ Moreover, in the case of hidden caries lesions and interproximal dentinal lesions diagnosed only by radiographic examination, the possibility of removing enamel with a manual instrument to gain access to the cavity is minimal and may tire the operator and cause discomfort to the patient. On the other hand, enamel removal is made easier with a rotary instrument, but this is not provided for in ART. Therefore, the patient would not be totally benefitted by this important, less invasive technique.

Considering that dental services in Brazil are performed with conventional equipment, in both the public and private sector, the following question ensues: Why not adapt this technique to our reality? This is how ARTm was proposed. It evolved from a doctoral thesis in Pediatric Dentistry begun in $1998^{2}$ and later made known to the scientific community. ${ }^{3,4}$ In the ARTm technique, the high-speed rotating diamond burr should be restricted to use on enamel, a dental structure that lacks sensitivity to being cut and that requires no use of anesthesia. Only unsupported enamel is removed and in smallopening dentinal lesions, or else lesions that are not clinically visible, thus preserving as much structure as possible, in keeping with the principle of minimum intervention. This eliminates two consequential factors of the original ART: manual fatigue of the operator and discomfort of the patient. Use of the reflector, the triple syringe and the saliva ejector makes it easier to visualize the site and control moisture accumulation in the operative field, thus enabling more suitable application of restorative material. These benefits were later confirmed in studies that concluded that the use of this equipment enables better results. ${ }^{6,7}$ It is important to point out that, just as in the original ART technique, ARTm provides for the removal of the affected dentinal tissue exclusively with manual instruments.

The claim that a rotary instrument causes greater pain and discomfort than a manual instrument is based on studies that compared ART to the conventional restorative treatment. ${ }^{8-11}$ Considering that a rotary instrument was used in these studies to remove carious dentin, these results cannot be inferred to ARTm. It is widely known that low-speed vibration on dentin may cause discomfort, which does not occur with ARTm. What is in fact observed is that modified ART may lessen the resistance to using this approach, and make it more readily accepted not only by patients, but also by Brazilian professionals. Nonetheless, the literature admittedly lacks studies comparing the original to the modified technique. Frencken and Amerongem ${ }^{12}$ stated that

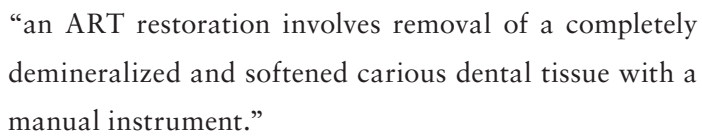

On the other hand, Holmgren and Fiqueiredo ${ }^{13}$ said that the reason for using manual instruments is

\footnotetext{
"to remove softened, highly infected and unremineralizable dentin to leave the affected dentin minimally infected and remineralizable, ultimately preserving the healthy dental structure."
}

It becomes evident, therefore, that ARTm complies with this principle of minimum intervention, also applicable to the original technique, and that there is no reason not to use the rotary instrument in the specific situations mentioned earlier.

The importance of the original ART is still recognized, but is regarded in the dental community as a technique that applies only when dental equipment is unavailable, such as the case of bed-ridden patients or dental services provided to Indians in their villages as part of the National Indian Community Assistance Program. ${ }^{14}$ ART and ARTm are low cost techniques designed to restore a greater number of cavities in a shorter period of time, so that the dental professional may assist a large number of patients and check the progression of lesions more quickly. To Brazil, both techniques represent the possibility of increasing universal access of the population to dental assistance and resolving the buildup of needs.

When a small change was made in the original technique to adapt it to the Brazilian reality, it was decided that the letter " $m$ " would be added to the ART acronym for ethical reasons. The ARTm acronym, therefore, expresses the respect and acknowl- 
edgement of the immeasurable importance of the initiative by Prof. Jo Frencken and collaborators taken in the mid-1980s. Thanks to this initiative, we have a relevant strategy called Modified Atraumatic Restorative Treatment (ARTm) in place today and widely used in our country to manage and control dental caries. Many Brazilians are benefitted by treatment with the ARTm technique, and the trend is for more dentists to adopt and use this modified

\section{References}

1. Massara MLA, Wambier DS, Imparato JCP. Tratamento restaurador atraumático. In: Massara MLA, Rédua PCB (coordenadores). Manual de Referência para Procedimentos Clínicos em Odontopediatria. São Paulo: Santos, 2012. p. 156-63.

2. Massara MLA. Técnica de mínima intervenção em lesões cariosas de dentina de molares decíduos: análises clínica, ultraestrutural e química [tese]. Belo Horizonte: Instituto de Ciências Biológicas da Universidade Federal de Minas Gerais; 2001.

3. Massara ML, Alves JB, Brandão PR. Atraumatic restorative treatment: clinical, ultrastructural and chemical analysis. Caries Res. 2002 Nov-Dec;36(6):430-6.

4. Massara MLA. ART Modificado: a melhor abordagem de lesões de dentina da atualidade. In: $11^{\circ}$ Livro Anual do Grupo Brasileiro de Professores de Ortodontia e Odontopediatria. Odontologia infantil brasileira - momento atual -- Belo Horizonte: GPBOO, 2002. p. 131.

5. Navarro MF, Rigolon CJ, Barata TJ, Bresciane E, Fagundes TC, Peters MC. Influence of occlusal access on demineralized dentin removal in the atraumatic restorative treatment (ART) approach. Am J Dent. 2008;21(4):251-4.

6. Faccin ES, Ferreira SH, Kramer PF, Ardenghi, TM, Feldens CA. Clinical performance of ART restorations in primary teeth: a survival analysis. J Clin Ped Dent. 2009 Summer;33(4):295-8.

7. Honkala E, Behbehani J, Ibricevic H, Kerosuo E, Al-Jame G. The atraumatic restorative treatment (ART) approach to restorative primary teeth in a standard dental clinic. Int J Paediatr Dent. 2003 May;13(3):172-9. technique.

Finally, it is important to highlight that ARTm has been recommended by the Brazilian Association of Pediatric Dentistry ${ }^{1}$ and the Ministry of Health. The use of the modified technique is provided in the "Guidelines for Oral Health Care in Indigenous Health Districts", a document of the National Health Foundation (FUNASA - Fundação Nacional de Saúde). ${ }^{14}$

8. Rahimtoola S, van Amerongen WE, Maher R, Groen H. Pain related to different ways of minimal intervention in the treatment of small caries lesions. ASDC J Dent Child. 2000 MarApr;67(2):123-7, 83.

9. Schriks MC, van Amerongen WE. Atraumatic perspectives of ART: psychological and physiological aspects of treatment with and without rotary instruments. Community Dent Oral Epidemiol. 2003 Feb;31(1):15-20.

10. Leal SC, Menezes Abreu DM, Frencken JE. Dental anxiety and pain related to Atraumatic Restorative Treatment. J Appl Oral Sci. 2009;17 Spec Issue:84-8.

11. Menezes Abreu DM, Leal SC, Frencken JE. Self-report of pain in children treated according to the atraumatic restorative treatment and the conventional restorative treatment-a pilot study. J Clin Pediatr Dent. 2009 Winter;34(2):151-5.

12. Frencken JE, van Amerongen WE. The Atraumatic RestorativeTreatment approach. In: Fejerskov O, Kidd E, Bente N, editors. Dental caries: the disease and its clinical management. $2^{\text {nd }}$ ed. Oxford (UK): Blackwell Munksgaard; 2008. p. 427-42.

13. Holmgren CJ, Figueireco MC. Two decades of ART: improving on success trough further research. J Appl Oral Sci. 2009;17 Suppl:122-33.

14. Fundação Nacional de Saúde (FUNASA). Diretrizes para a saúde bucal nos distritos sanitários especiais indígenas. 2007 [Internet]. Brasília (DF): Ministério da Saúde; 2007 [cited 2012 May 05]. Available from: http://www.funasa.gov.br/ internet/arquivos/biblioteca/sauInd_bucal.pdf. 